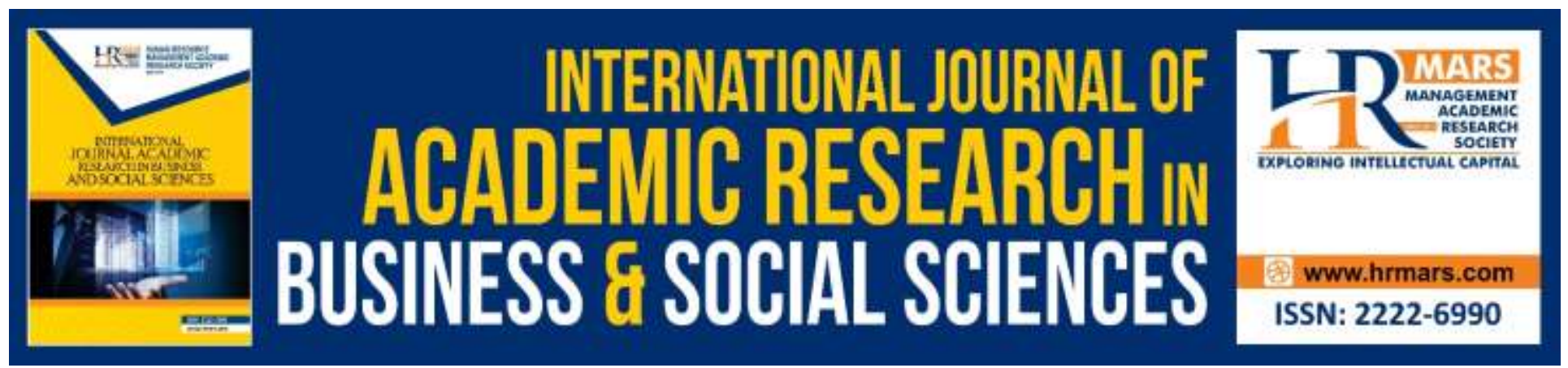

\title{
Expatriate Cross-Cultural Adjustment in Selected Multinational Company in Malaysia
}

Nurazree Mahmud, Amir Hamzah Mohd Zainal, Ahmad Fadhly Arham, Helmy Fadlisham Abu Hasan

To Link this Article: http://dx.doi.org/10.6007/IJARBSS/v10-i5/7191 DOI:10.6007/IJARBSS/v10-i5/7191

Received: 11 March 2020, Revised: 16 April 2020, Accepted: 25 April 2020

Published Online: 02 May 2020

In-Text Citation: (Mahmud et al., 2020)

To Cite this Article: Mahmud, N., Zainal, A. H. M., Arham, A. F., \& Hasan, H. F. A. (2020). Expatriate Cross-Cultural Adjustment in Selected Multinational Company in Malaysia. International Journal of Academic Research in Business and Social Sciences, 10(5), 239-251.

\section{Copyright: (C) 2020 The Author(s)}

Published by Human Resource Management Academic Research Society (www.hrmars.com)

This article is published under the Creative Commons Attribution (CC BY 4.0) license. Anyone may reproduce, distribute, translate and create derivative works of this article (for both commercial and non-commercial purposes), subject to full attribution to the original publication and authors. The full terms of this license may be seen at: http://creativecommons.org/licences/by/4.0/legalcode

Vol. 10, No. 5, 2020, Pg. 239 - 251

Full Terms \& Conditions of access and use can be found at http://hrmars.com/index.php/pages/detail/publication-ethics 


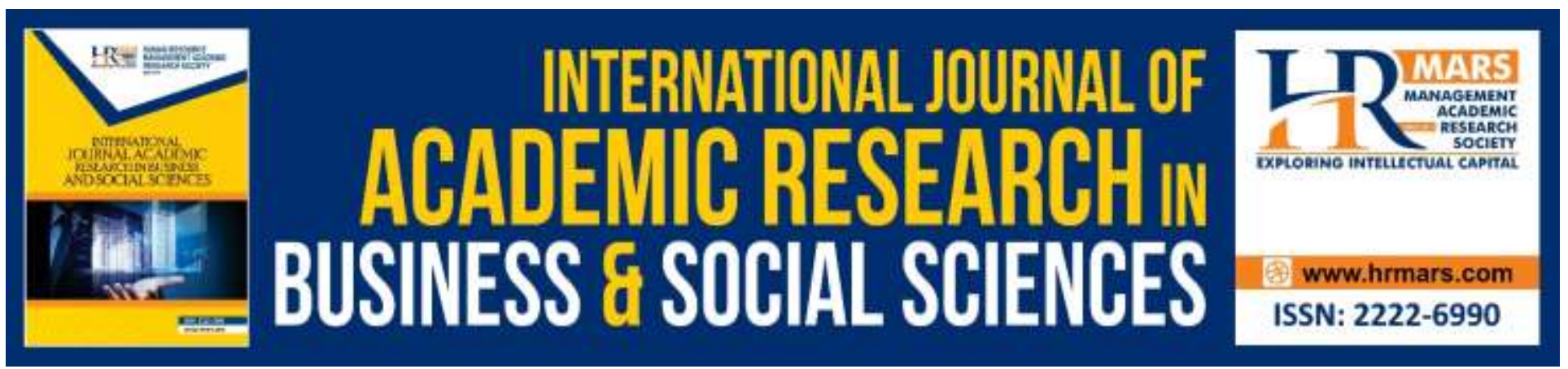

\title{
Expatriate Cross-Cultural Adjustment in Selected Multinational Company in Malaysia
}

\author{
Nurazree Mahmud, Amir Hamzah Mohd Zainal, Ahmad Fadhly \\ Arham, Helmy Fadlisham Abu Hasan \\ Faculty of Business \& Management/ Universiti Teknologi MARA, Melaka, Malaysia. \\ Email: nurazree642@uitm.edu.my
}

\begin{abstract}
Expatriate and expatriation have become a norm in today's business environment where business operations transcend beyond national border. Globalization had provided the opportunity for entrepreneurs and corporations to expand their market and fulfilled the potential for growth in other geographic area. The study aimed to discuss the elements that influenced expatriate cross-cultural adjustment during their international assignment in Malaysia. A theoretical framework consisted of three variables; personality traits, cultural intelligence and spousal/family support was developed. The fundamental question addressed in this study was to determine the factors that influenced expatriate cross-cultural adjustment. The research objective was to examine the relationship between the personality traits, cultural intelligence and spousal/family support towards expatriate cross-cultural adjustment. Expatriates that are employed in multinational corporations (MNCs) and had resided in Malaysia for a period of more than six months were chosen as respondents for the study. Data were collected through questionnaire distributed to 103 expatriates using nonprobability sampling. Statistical methods conducted to analyze data included frequency, reliability and multiple regression analysis. Based on the analysis, the findings indicated that personality traits and cultural intelligence had a significant and positive relationship toward expatriate cross-cultural adjustment.
\end{abstract}

Keywords: Expatriate, Multinational Corporations, Personality Traits, Cultural Intelligence, CrossCultural.

\section{Introduction}

Expatriation and international assignments have been an important subject matter in multiple streams of literature as an integral part of international business. Economic globalization and the need to conduct operation around the globe, has become a reality of organizational life. Historically, expatriates were managers from the headquarter of a multinational corporations (MNCs) who moved to a foreign country to manage and control a subsidiary. The early 2000s saw a new trend in international business, which includes expansion of a new market in emerging economies such as China, South Korea and India. Expansion in these emerging economies provide new challenges, as 
there were larger economic and cultural distance between the home and host countries. MNCs began to explore alternative forms of international assignment in order to cope with these new challenges. Selection criteria based on family situation, personal characteristics were explored (Harvey and Moeller, 2009), and there was an increase in expatriate training prior to international assignment (Romero, 2002). Scholars had also started exploring expatriation and international assignment specific to a country or culture to address the challenges of expatriate adjustment (Makela, Kansala \& Suutari, 2011).

Nowadays, many MNCs depend on expatriates because of their unique skillset, working experience and understanding of home country values and way of doing things. Recent technological advancement had led to a more efficient international travel in which it allows corporations to adopt alternative form of expatriation (Shankaran et al., 2011). According to Collings et al. (2018), the alternative forms of expatriation involve short-term expatriation, virtual assignments, business traveler and international commuter. These variations of expatriation reduce the burden of an expatriate by not having to relocate for extended periods or become engrossed in the foreign culture.

Although many studies have been conducted exploring expatriate adjustment, (Peltokorpi \& Froese 2012; Lee, Veasna and Wu 2013; Chen \& Shaffer 2017), research within the context of Malaysian environment is still in its infancy stage (Hassan and Diallo 2013; Sambasivan, Sadoughi and Esmaeilzadeh 2017). According to Hofstede (1980) as cited by Sambasivan et al. (2017), they stated that Malaysia is a country that is characterized as having a high-power distance and collectivism. The country had experienced a unique ethnic diversity as well as rich cultural and historical background, which may create some challenges for expatriate to properly adapt and adjust (Kennedy, 2002). Hence, finding the right formula to adjust to the Malaysian culture is the key for expatriates to maximize their performance.

Premature expatriate return from international assignment is a worrying problem for many employers. Failing expatriate is an alarming situation that gives a bad affect to the MNCs operation in the foreign country. Cultural differences between the home and the host country had deter the success rate of these expatriates. Researchers had argued that inadequate adjustment to the foreign culture was the main reason of low performance contributing to high expatriate failure rates (Kraimer, Wayne \& Jaworski, 2001). Their incapability to adjust to the foreign culture leads to failure to deliver the expected result set by the top management. In general, there have not been a declining trend of expatriate failure over time (Pires, Stanton and Ostenfield, 2006).

MNCs are considering Malaysia as a major marketplace to expand their business operation. As such, various sectors and industries are expected to have continuous rate of expatriate employed. The upward trend in the number of expatriates and international assignments in Malaysia have amplified the need for studies to understand the adaptation process of the expatriate during their assignment in Malaysia. This study perhaps may assist corporation to identify the elements needed to be considered into their decision-making process prior to sending the expatriates on international assignments. It will also contribute to better expatriate job performance and prevent premature return. Therefore, this paper is intended to examine:

- the relationship between personality traits and expatriate cross-cultural adjustment

- the relationship between cultural intelligence and expatriate cross-cultural adjustment 
INTERNATIONAL JOURNAL OF ACADEMIC RESEARCH IN BUSINESS AND SOCIAL SCIENCES

Vol. 10, No. 5, May, 2020, E-ISSN: 2222-6990 @ 2020 HRMARS

- the relationship between spousal and family support and expatriate cross-cultural adjustment

\section{Literature Review}

\section{Expatriation in Multinational Corporations}

Expatriate is an individual that resides outside their native country temporarily or permanently (Ott and Michailova, 2016). According to Tan and Mahoney (2006), expatriates refer to citizens from MNCs home country who are sent by the headquarters to its foreign subsidiaries for a period of 3 years or longer. Expatriation may promote inter-subsidiary communication and coordination (Cantoni and Giustiniano, 2015) by moving together with the expatriate overall corporate culture and vision of the MNCs. According to Sambasivan et al. (2017), expatriation has become a vital source of competitive advantage for numerous MNCs. These corporations are progressively becoming more dependent on expatriates for a variety of purposes. According to Hassan and Diallo (2013), MNCs relied on expatriates to maintain their identity and protecting its brand. Ramulu et al. (2010) also mentioned that expatriate facilitates in spreading and sustaining corporate culture. Expatriate performs an important role for the organization in terms of administrating, coordinating and transferring the knowledge, information and intelligence in between multinational and international businesses (Lee and Crocker, 2006).

\section{U-curve theory of Adjustment and Cross-cultural Adjustment}

This study adopts the u-curve theory (UCT) of adjustment to better understand the expatriate cross-cultural adjustment. It has been used to describe expatriate cross-cultural adjustment within a host culture. Adjustment is depicted as having a growing degree of contentment in being able to deal effectively within a foreign country (Liu and Lee, 2008). Expatriate adjustment arises from having a better understanding and knowledge of local culture. The theory suggests that an expatriate will be going through four different stages of adjustment.

The first stage is called the "honeymoon phase" in which an expatriate started to work in foreign country and felt excited about the new things he or she encountered. Expatriate will be fascinated by the unfamiliar and different culture. The feeling of being a "tourist" during the first few weeks and months are unavoidable (Black and Mendehall, 1991). The second stage is often called the "culture shock phase". It began with expatriates slowly to have feeling of despair and stress. They also started to feel low and even physically ill as they realize the reality of work life of their international assignment (Liu and Lee, 2008). This stage often last from the sixth to twelfth months.

If expatriates choose to persist and resist the temptation to quit, they will enter the third stage called the "adjustment phase". According to Kong and Foon (2009), expatriates can adjust by altering the new role to better fit themselves or by altering their own personalities, traits and manners to suit the new role. During this adjustment phase, expatriates begin to develop capability to act appropriately that will lead to a more positive emotional state (Black and Mendehall, 1991). Finally, in the fourth stage, the "mastery phase", expatriates will be getting better at interpreting new social cues, can slide past the communication breakdown and settle their identity crisis (Liu and Lee, 2008). Expatriates will be able to perform effectively in the setting of the host culture and provide a greater impact than they previously could.

Cross-cultural adjustment (CCA) can be termed as familiarity of expatriate to different attributes of foreign culture and the degree in which they are psychologically comfortable (Black and 
Mendehall, 1990). It is the perceived adaptation process of residing and operating in a foreign culture (Palthe, 2004). According to Huff (2013), the widely used method to address this concern is to measure the CCA. CCA had been closely linked with the intention to stay by expatriates (Black and Gregersen, 1991). This is also supported by Fe Causin, Ayoun and Moreo (2011) that identified CCA as an important factor for successful expatriation.

\section{Personality traits and Cross-cultural Adjustment}

Personality traits can be defined as antecedents of an individual conduct that reflect their pattern of thought, emotion and behavior (Guthrie, Ash and Stevens, 2003). According to Padilla and Perez (2003), personality traits can influence individual's social interaction and adjustment as a form of social cognition. Earlier definition of personality traits is broader in which it covers the interpersonal, attitudinal, emotional, experiential and motivational style that describe individual's manner in various circumstances (McCrae \& Costa, 1989).

Numerous studies surrounding the topic of expatriation had endorsed the impact of the Big Five during international assignments to complement expatriate's psychological attribute (Downes et al., 2010). There are also studies that suggested personality traits such as self-efficacy, being open to experience new things and consciousness to be important factors that influence expatriate crosscultural adjustment (Hechanova et al, 2003 as cited in Guthrie et al, 2003).

Ramalu et al. (2010) stated that there is a perfected relationship between personality traits and expatriate cross-cultural adjustment in Malaysia. They further stated that personality such as openness and friendliness will greatly influence expatriate general adjustment. This is parallel to the finding of Kumar et al. (2008) in which the personality traits are considered as one of the key indicators of a successful international assignment. As such, this will make the following hypothesis:

H1. There is a positive relationship between personality traits and expatriate cross-cultural adjustment.

\section{Cultural Intelligence and Cross-cultural Adjustment}

Cultural intelligence can be termed as the abilities of an individual to perform effectively and manage conflicts in diverse cultural environment (Ang \& Van Dyne, 2015). Previous studies had linked cultural intelligence to stress levels during international travel (Ramsey et al., 2011) and cross-cultural negotiation results (Imai and Gelfand, 2010). By focusing on the cultural differences around them and by being more culturally intelligent, expatriates can reduce the uncertainty and better manage their anxiety which may lead to better adjustment and improved job performance. This is parallel to the finding of Kumar et al. (2008) in which cultural intelligence signifies an important intercultural capacity that is critical for expatriate in an international assignment. He further explained that expatriates with higher cultural intelligence are expected to understand unfamiliar culture easily, better at adopting to local culture and assumed to be more effective during their international assignment. Thus, this paper posits that:

H2. There is a positive relationship between cultural intelligence and expatriate cross-cultural adjustment.

\section{Spousal/family support and Cross-cultural adjustment}

Spousal/family support can be defined as the support that individual received from their spouse or other family members (Uddin and Bhuiyan, 2019). They explained that family is the setting 
in which most individuals are born, grow, and mature whereas spouse is their life partner commonly bonded through marriage. For most individuals, family members and/or spouse provide a major and significant impact on their lives which influence their decision on opportunity and risk.

There are various studies in which past researchers discussed the importance of spousal/family support on expatriate adjustment (Kraimer et al, 2001; Haslberger and Brewster, 2008; Chen and Shaffer, 2017). The spousal/family support had also been addressed in accordance to the personality and expatriate performance to determine its direct relationship (Hassan and Diallo, 2013). According to Sambasivan et al. (2017), the effectiveness of expatriate in foreign country largely depended on the happiness of their spouse or family members in the foreign environment.

Earlier empirical study had shown contradicting findings on the relationship between spousal/family support and expatriate cross-cultural adjustment. According to Shaffer et al. (2006), spouse/family members may hinder expatriate adjustment in foreign country. They argued that when the spouse/family members relocate together with expatriates, the attention would be more towards them and lead to lesser contact with the host culture. It would significantly reduce the degree of interaction and may lead to weaker cross-cultural adjustment.

In contrast, many studies had hypothesized that there is a positive relationship between spousal support and adjustment (Caliguiri et al., 1998, 1999; Harvey, 1998 as cited in Kraimer, 2001). Lee (2007) suggested that there is a strong association between spousal/family support and expatriate cross-cultural adjustment. Thus, this paper hypothesized that:

H3. There is a positive relationship between spousal/family support and expatriate crosscultural adjustment.

\section{Methodology}

The identified population of this group was the expatriates who are working in the MNCs in Federal Territory of Kuala Lumpur, Malaysia. For the sampling technique, convenience sampling was deployed in this study. Presently, there is no statistic available to show the population of expatriates currently working in Kuala Lumpur for 2019. Statistics from previous studies cannot be replicated in this study since it may not show the current population of the expatriates since mobilization and demobilization turnover rate are very high. The sample size of this study comprised of 103 respondents, who are expatriates currently employed in MNCs and have been residing in Malaysia for at least six months.

The questionnaire prepared in this research consists of five sections with a total of 37 items. Section A represents the Demographic questions to obtain respondents' profiles. It includes age, gender, marital status, education level, years of working internationally, experience working in Malaysia, job sector, job position level and annual income. Section B comprises questions regarding the dependent variable of this research which is cross cultural adjustment. Whereas, section C, D and $E$ represent questions pertaining the independent variables - personality traits, cultural intelligence and spousal/family report, respectively. Section B to E were designed in the form of Likert scale and all items were adapted from previous research (Hassan and Diallo, 2013; Lee at al., 2013; Uddin and Bhuiyan, 2019). 
INTERNATIONAL JOURNAL OF ACADEMIC RESEARCH IN BUSINESS AND SOCIAL SCIENCES Vol. 10, No. 5, May, 2020, E-ISSN: 2222-6990 @ 2020 HRMARS

\section{Results}

Reliability Analysis

Table 1 shows the reliability analysis for all the variables. It reflects that all four variables used in this study exceed the minimum Cronbach's Alpha coefficient value of 0.7 . The variable with the highest Cronbach's Alpha coefficient value is spousal/family support $(\alpha=0.862)$, followed by expatriate cross-cultural adjustment $(\alpha=0.861)$, personality traits $(\alpha=0.825)$ and lastly cultural intelligence $(\alpha=0.813)$. In general, all variables possess a good internal consistency given the range of Cronbach's Alpha are between $0.80-0.90$. Hence, it shows that the instruments measuring these variables are reliable and valid for this study.

Table 1 Reliability analysis

\begin{tabular}{|c|c|c|}
\hline Variable & Number of items & Cronbach's Alpha \\
\hline spousal/family support & 7 & 0.862 \\
\hline personality traits & 6 & 0.825 \\
\hline cultural intelligence & 7 & 0.813 \\
\hline $\begin{array}{c}\text { expatriate cross-cultural } \\
\text { adjustment }\end{array}$ & 8 & 0.861 \\
\hline
\end{tabular}

Demographic Profile of Respondents

Table 2 below shows the profile of respondents. It included gender, age, marital status, education level, experience working internationally, experience working in Malaysia, job sector, job position level and annual income. Male respondents exceeded the number of female respondents with 62.1 percent $(n=64)$ and 37.9 percent $(n=39)$ respectively. There is a difference of 24.2 percent between male and female respondents, which represented by 25 respondents. This is consistent with the findings by other researcher where there are more male expatriates as compared to female (Sambasivan et al., 2017). Majority of the respondents aged between 30-39 years in which it represents 61.1 percent of the total respondents. In total, 57.3 percent of the respondents were married, and the remaining were single. About 78.6 percent of the respondents were Bachelor degree holders, 19.4 percent were Master degree holders and remaining 1.9 percent were Doctor of Philosophy holders. 
INTERNATIONAL JOURNAL OF ACADEMIC RESEARCH IN BUSINESS AND SOCIAL SCIENCES Vol. 10, No. 5, May, 2020, E-ISSN: 2222-6990 (c) 2020 HRMARS

Table 2 Respondents profile

\begin{tabular}{|c|c|c|c|}
\hline \multicolumn{2}{|c|}{ Items } & Frequency & Percentage \\
\hline \multirow{4}{*}{ Age } & 29 years and below & 25 & 24.2 \\
\hline & $30-39$ & 63 & 61.1 \\
\hline & $40-49$ & 13 & 12.7 \\
\hline & 50 years and above & 2 & 2.0 \\
\hline \multirow[t]{2}{*}{ Gender } & Male & 64 & 62.1 \\
\hline & Female & 39 & 37.9 \\
\hline \multirow[t]{2}{*}{ Marital status } & Single & 44 & 42.7 \\
\hline & Married & 59 & 57.3 \\
\hline \multirow[t]{3}{*}{ Education level } & Bachelor degree & 81 & 78.6 \\
\hline & Master degree & 20 & 19.4 \\
\hline & $\mathrm{PhD}$ & 2 & 1.9 \\
\hline \multirow{5}{*}{$\begin{array}{l}\text { Experience working } \\
\text { internationally }\end{array}$} & No previous experience & 22 & 21.4 \\
\hline & Less than 1 year & 31 & 30.1 \\
\hline & $1-2$ years & 30 & 29.1 \\
\hline & $3-5$ years & 15 & 14.6 \\
\hline & More than 5 years & 5 & 4.9 \\
\hline \multirow{4}{*}{$\begin{array}{l}\text { Experience working } \\
\text { in Malaysia }\end{array}$} & $7-11$ months & 36 & 35.0 \\
\hline & $1-2$ years & 41 & 39.8 \\
\hline & $3-5$ years & 23 & 22.3 \\
\hline & More than 5 years & 3 & 2.9 \\
\hline \multirow[t]{10}{*}{ Job sector } & $\begin{array}{l}\text { Accountancy, banking } \\
\text { and finance }\end{array}$ & 10 & 9.7 \\
\hline & $\begin{array}{c}\text { Business, consultation } \\
\text { and management }\end{array}$ & 47 & 45.6 \\
\hline & $\begin{array}{l}\text { Engineering and } \\
\text { manufacturing }\end{array}$ & 12 & 11.7 \\
\hline & $\begin{array}{c}\text { Healthcare \& } \\
\text { pharmaceutical }\end{array}$ & 2 & 1.9 \\
\hline & Information technology & 10 & 9.7 \\
\hline & Legal & 4 & 3.9 \\
\hline & $\begin{array}{l}\text { Marketing, advertising } \\
\text { and public relation }\end{array}$ & 6 & 5.8 \\
\hline & Oil \& gas & 5 & 4.9 \\
\hline & Transportation \& logistics & 3 & 2.9 \\
\hline & Others & 4 & 3.9 \\
\hline \multirow[t]{3}{*}{ Job position level } & Junior level & 37 & 35.9 \\
\hline & Mid-level & 54 & 52.4 \\
\hline & Senior level & 12 & 11.7 \\
\hline \multirow[t]{5}{*}{ Annual income } & Below $\$ 20,000$ & 4 & 3.9 \\
\hline & $\$ 20,000-\$ 44,999$ & 38 & 36.9 \\
\hline & $\$ 45,000-\$ 139,999$ & 34 & 33.0 \\
\hline & $\$ 140,000-\$ 149,999$ & 21 & 20.4 \\
\hline & $\$ 150,000-\$ 199,999$ & 6 & 5.8 \\
\hline
\end{tabular}


Majority of the respondents had previous experience working internationally. The highest recorded were respondents with less than 1-year experience which contributed 30.1 percent, followed by respondents with 1-2 years of experience which contributed 29.1 percent. However, it turns out that 21.4 percent of the respondents do not serve in any international assignment prior to their current employment in Malaysia.

As of experience of working in Malaysia, only 2.9 percent respondents had more than 5 years of working experience in Malaysia and majority of respondents had 1-2 years of experience in which it represented 39.8 percent of the total respondents. The job sector variable was divided into ten categories. The highest recorded job sector was from business, consultation \& management, which contributed 45.6 percent of the total respondents, followed by engineering \& manufacturing with 11.7 percent, accountancy, banking \& finance and information technology with both scored 9.7 percent respectively. The lowest job sector was health \& pharmaceutical with only 1.9 percent. The job position level is divided into three different categories; junior level, mid-level and senior level. From the finding, majority of the respondents were expatriates from mid-level position which contributed 52.4 percent. Junior-level position came in second with 35.9 percent or 37 respondents. The least job positon level was the senior level which contributed only 11.7 percent or 12 respondents. For the annual income, 36.9 percent of the respondents received $\$ 20,000-\$ 44,999$ annually. Next, 33 percent received earned $\$ 45,000$ - \$139,999 annually, followed by 20.4 percent that earn $\$ 140,000$ - $\$ 149,999,5.8$ percent that earned $\$ 150,000$ - $\$ 199,999$ and 3.9 percent that earned below $\$ 20,000$.

\section{Multiple Regressions Analysis}

This research used the regression analysis to test the model or relationship between independent and dependent variables. Table 3 shows the regression result. It is reflected that the coefficient of determination's value is $R^{2}=0.677$. The value indicated that $67.7 \%$ of expatriate crosscultural adjustment can be explained by the independent variables, which are personality traits, cultural intelligence and spousal/family support. The other $33.3 \%$ of variation can be explained by other variables which are not included in this study. In addition, cultural intelligence had the highest beta coefficient value with $\beta=0.588$. The model shows that with every increase of one standard deviation in cultural intelligence, the expatriate cross-cultural adjustment rises by 0.588 of a standard deviation. It can be deduced that cultural intelligence contributed the greatest impact on expatriate cross-cultural adjustment since it had the highest beta coefficient value. The higher the level of cultural intelligence, the higher the level of expatriate cross-cultural adjustment.

As for the significance of each variable towards the dependent variable, it has been analyzed that personality traits and cultural intelligence significantly influences cross cultural adjustment with a significant value of $\mathrm{p}<0.05$ which valued at 0.005 and 0.000 . Thus, $\mathrm{H} 1$ and $\mathrm{H} 2$ are supported. However, for the other independent variable - spousal/family support, the results turned out to be not significant at the value of 0.168 , as they are not within $p<0.01$ or even $p<0.05$. Thus, $\mathrm{H} 3$ is rejected. 
INTERNATIONAL JOURNAL OF ACADEMIC RESEARCH IN BUSINESS AND SOCIAL SCIENCES Vol. 10, No. 5, May, 2020, E-ISSN: 2222-6990 @ 2020 HRMARS

Table 3 Result of multiple regression

\begin{tabular}{|c|c|c|}
\hline \multicolumn{3}{|c|}{ Dependent variable: Cross cultural adjustment } \\
\hline Independent variables & $\begin{array}{c}\text { Standardised Coefficient } \\
\text { (BETA) }\end{array}$ & Sig. \\
\hline personality traits & 0.221 & 0.005 \\
\hline cultural intelligence & 0.588 & 0.000 \\
\hline spousal/family support & 0.128 & 0.168 \\
\hline F value & 69.142 & \\
\hline R square & 0.677 \\
\hline
\end{tabular}

\section{Implications and Conclusion}

The researchers are able to achieve the aim of this study by examining the relationship between the independent variables (personality traits, cultural intelligence and spousal/family support) and the dependent variable (expatriate cross-cultural adjustment). The researchers discovered that there is a significant and positive relationship between personality traits and expatriate cross-cultural adjustment. This finding is parallel to the studies made by Shaffer et al. (2006), Kumar et al. (2008), Ramalu et al. (2010) and Awais Bhatti et al. (2014). Personality traits such as extraversion, conscientiousness, agreeableness, openness to experience and neuroticism commonly known as the Big Five have been found significantly and positively influence the cross-cultural adjustment of expatriate (Caliguiri, 2000). Similarly, Hassan and Diallo (2013), a study done on Malaysia context, also revealed that it is relevant to measure the personality traits of expatriate since there is a strong relationship with cultural adjustment. They argued that personal traits of expatriate such as positive mindset, desire to work overseas and comfortable to work-outside would highly influence the cultural adjustment of expatriates and their ability to adjust to the new working places. The researchers also discovered that there is a significant and positive relationship between cultural intelligence and expatriate cross-cultural adjustment. Earlier study had shown that cultural intelligence was associated to multiple facets of adjustments (Ang et al., 2007; Huff, 2013). Sambasivan et al. (2017) stated that there is a direct effect of cultural intelligence on adjustment. Hence, the finding of this study provides further support that cultural intelligence is important for expatriate cross-cultural adjustment.

With regards to this significant relationship, there are several suggestions that can be implement by MNCs and managers for continuous improvement of current practice and procedure. International human resource (HR) managers of respective MNCs should highly consider the psychological aspects of expatriates mainly their personality traits when evaluating candidates to be assigned for international assignment. HR managers should consider several personality traits that will facilitate expatriates to perform efficiently and effectively in foreign environment. Among the most used standards for evaluating an individual's personality traits are the Big Five Personality Test. These traits, especially the Big Five must be examined and scanned before selecting suitable expatriate. Expatriate who lack these traits will have higher percentage to fail in their international assignment (Caliguiri, 2000). Moreover, MNCs should provide cultural training to their employees in order to enhance their cultural intelligence. According to Huff (2013), the cognitive cultural intelligence can be acquired and enhanced through both educational and personal experiences. He further stated that expatriate with higher cultural intelligence would be more effective to adapt to different culture compared to those with low cultural intelligence. MNCs should identify expatriate 
candidates with the desired personality traits and then offer a cross-cultural training to the potential candidates. By providing cultural training, expatriates will be more aware on the cultural sensitivity of the local culture so that they can best avoid it. In a way, cultural training complements the personality traits and enhances cultural intelligence.

Apart from these implications, the researchers also urged to consider on several matters to be included in future research. For this study, the researchers only focus on expatriates working in MNCs in certain area. Future study on this topic can widen the scope to include expatriates from other area/region in Malaysia and can be enhanced to other industries and organizations such as academic institutions and small and medium enterprises (SMEs). The same framework can be used on expatriates from different settings in order to strengthen or validate the findings of this study. Next, future study should identify whether the respondents are from self-initiated expatriates or organizational expatriates. Organizational expatriates are employees chosen by their organizations or MNCs to perform an international assignment whereas self-initiated expatriates are the one who volunteers to do so. Accordingly, there should be a study to measure the differences in term of crosscultural adjustment between these two different groups.

\section{References}

Ang, S., \& Van Dyne, L. (2015). Handbook of cultural intelligence: Theory, measurement, and applications. Routledge.

Ang, S., Van Dyne, L., Koh, C., Ng, K. Y., Templer, K. J., Tay, C., \& Chandrasekar, N. A. (2007). Cultural intelligence: Its measurement and effects on cultural judgment and decision making, cultural adaptation and task performance. Management and organization review, 3(3), 335-371.

Bhatti, A. M., Battour, M., Ismail, R. A., \& Sundram, P. V. (2014). Effects of personality traits (big five) on expatriates adjustment and job performance. Equality, Diversity and Inclusion: An International Journal, 33(1), 73-96.

Black, J. S., \& Gregersen, H. B. (1991). Antecedents to cross-cultural adjustment for expatriates in Pacific Rim assignments. Human relations, 44(5), 497-515.

Black, J. S., \& Mendenhall, M. (1990). Cross-cultural training effectiveness: A review and a theoretical framework for future research. Academy of management review, 15(1), 113-136.

Black, J. S., \& Mendenhall, M. (1991). The U-curve adjustment hypothesis revisited: A review and theoretical framework. Journal of international business studies, 22(2), 225-247.

Caligiuri, P. M. (2000). The big five personality characteristics as predictors of expatriate's desire to terminate the assignment and supervisor-rated performance. Personnel psychology, 53(1), 6788.

Caligiuri, P. M., Hyland, M. M., Joshi, A., \& Bross, A. S. (1998). Testing a theoretical model for examining the relationship between family adjustment and expatriates' work adjustment. Journal of Applied Psychology, 83(4), 598.

Caligiuri, P. M., Joshi, A., \& Lazarova, M. (1999). Factors influencing the adjustment of women on global assignments. International Journal of Human Resource Management, 10(2), 163-179.

Cantoni, F., \& Giustiniano, L. (2015). Developing organizational resilience via international mobility: a conceptual framework. Vita e Pensiero, 106, 1-42.

Chen, Y. P., \& Shaffer, M. A. (2017). The influences of perceived organizational support and motivation on self-initiated expatriates' organizational and community embeddedness. Journal of World Business, 52(2), 197-208. 
Collings, D. G., \& Isichei, M. (2018). The shifting boundaries of global staffing: integrating global talent management, alternative forms of international assignments and non-employees into the discussion. The International Journal of Human Resource Management, 29(1), 165-187.

Downes, M., Varner, I. I., \& Hemmasi, M. (2010). Individual profiles as predictors of expatriate effectiveness. Competitiveness Review: An International Business Journal, 20(3), 235-247.

Fe Causin, G., Ayoun, B., \& Moreo, P. (2011). Expatriation in the hotel industry: An exploratory study of management skills and cultural training. International Journal of Contemporary Hospitality Management, 23(7), 885-901.

Guthrie, J. P., Ash, R. A., \& Stevens, C. D. (2003). Are women "better" than men? Personality differences and expatriate selection. Journal of Managerial Psychology, 18(3), 229-243.

Harvey, M., \& Moeller, M. (2009). Expatriate managers: A historical review. International Journal of Management Reviews, 11, 275-296.

Haslberger, A., \& Brewster, C. (2008). The expatriate family: an international perspective. Journal of Managerial Psychology, 23(3), 324-346.

Hassan, Z., \& Diallo, M. M. (2013). Cross-cultural adjustments and expatriate's job performance: a study on Malaysia. International Journal of Accounting and Business Management,(IJABM), $1(1), 8-23$.

Huff, K. C. (2013). Language, cultural intelligence and expatriate success. Management Research Review, 36(6), 596-612.

Imai, L., \& Gelfand, M. J. (2010). The culturally intelligent negotiator: The impact of cultural intelligence (CQ) on negotiation sequences and outcomes. Organizational Behavior and Human Decision Processes, 112(2), 83-98.

Kennedy, J. C. (2002). Leadership in Malaysia: Traditional values, international outlook. Academy of Management Perspectives, 16(3), 15-26.

Kong, E., \& Foon, Y. (2009). Factors that influence Malaysian expatriate performance on global assignments (Doctoral dissertation, University Malaya).

Kraimer, M. L., Wayne, S. J., \& Jaworski, R. A. A. (2001). Sources of support and expatriate performance: The mediating role of expatriate adjustment. Personnel Psychology, 54(1), 7199.

Kumar, N., Che Rose, R., \& Sri Ramalu, S. (2008). The effects of personality and cultural intelligence on international assignment effectiveness: a review. Journal of Social Sciences, 4(4), 320-328.

Lee, L. Y., \& Croker, R. (2006). A contingency model to promote the effectiveness of expatriate training. Industrial Management \& Data Systems, 106(8), 1187-1205.

Lee, L. Y., Veasna, S., \& Wu, W. Y. (2013). The effects of social support and transformational leadership on expatriate adjustment and performance: The moderating roles of socialization experience and cultural intelligence. Career Development International, 18(4), 377-415.

Lee, P. C. (2007). Family support as a factor in cultural adjustment. Journal of Business Systems, Governance \& Ethics, 2(2), 29-35.

Liu, C. H., \& Lee, H. W. (2008). A proposed model of expatriates in multinational corporations. Cross Cultural Management: An International Journal.

Makela, L., Kansala , M., \& Suutari, V. (2011). The roles of expatriates' spouses among dual career couples. Cross Cultural Management: An International Journal, 18, 185-197

McCrae, R. R., \& Costa, P. T., Jr. (1989). More reasons to adopt the five-factor model. American Psychologist, 44(2), 451-452. 
INTERNATIONAL JOURNAL OF ACADEMIC RESEARCH IN BUSINESS AND SOCIAL SCIENCES

Vol. 10, No. 5, May, 2020, E-ISSN: 2222-6990 @ 2020 HRMARS

Ott, D. L., \& Michailova, S. (2016). Expatriate selection: A historical overview and criteria for decisionmaking. In Global talent management and staffing in MNEs (pp. 1-24). Emerald Group Publishing Limited.

Padilla, A. M., \& Perez, W. (2003). Acculturation, social identity, and social cognition: A new perspective. Hispanic Journal of Behavioral Sciences, 25(1), 35-55.

Palthe, J. (2004). The relative importance of antecedents to cross-cultural adjustment: Implications for managing a global workforce. International Journal of Intercultural Relations, 28(1), 37-59.

Peltokorpi, V., \& Froese, F. J. (2012). The impact of expatriate personality traits on cross-cultural adjustment: A study with expatriates in Japan. International Business Review, 21(4), 734-746.

Pires, G., Stanton, J., \& Ostenfeld, S. (2006). Improving expatriate adjustment and effectiveness in ethnically diverse countries: marketing insights. Cross Cultural Management: An International Journal, 13(2), 156-170.

Ramalu, S. S., Rose, R. C., Uli, J., \& Kumar, N. (2010). Personality and cross-cultural adjustment among expatriate assignees in Malaysia. International Business Research, 3(4), 96.

Ramsey, J. R., Leonel, N. J., Gomes, Z. G., \& Monteiro, R. R. P. (2011). Cultural intelligence's influence on international business travelers' stress. Cross Cultural Management: An International Journal, 18(1), 21-37.

Romero, E. J. (2002). The effect of expatriate training on expatriate effectiveness. Journal of Management Research, 2, 73-78

Sambasivan, M., Sadoughi, M., \& Esmaeilzadeh, P. (2017). Investigating the factors influencing cultural adjustment and expatriate performance: The case of Malaysia. International Journal of Productivity and Performance Management, 66(8), 1002-1019.

Shaffer, M. A., Harrison, D. A., Gregersen, H., Black, J. S., \& Ferzandi, L. A. (2006). You can take it with you: Individual differences and expatriate effectiveness. Journal of Applied psychology, 91(1), 109.

Shankaran, G., Murray, R. A., \& Miller, P. (2011). Short-term international assignments: Maximizing effectiveness, minimizing cost and risk. Int'I Tax J., 37, 41.

Tan, D., \& Mahoney, J. T. (2006). Why a multinational firm chooses expatriates: Integrating resourcebased, agency and transaction costs perspectives. Journal of Management Studies, 43(3), 457484.

Uddin MA, Bhuiyan AJ. (2019). Development of the family support scale (FSS) for elderly people, MOJ Gerontology and Geriatrics, 4(1):17-20. 